\title{
PARTISISPASI ANGGARAN DAN PERAN KUASA PENGGUNA ANGGARAN TERHADAP KINERJA KEUANGAN BERBASIS IT
}

\author{
Dina Maria \\ Universitas Karyadarma Kupang, NTT 85118 \\ dinamaria99dagama@gmail.com
}

\begin{abstract}
ABSTRAK
Lokasi penelitian pada Dispora Provinsi NTT yang beralamat di Jalan Basuki Rahmat No. 1 Gedung E Lt. 3 Kota Kupang NTT. Tujuan dari penelitian adalah gambaran umum dari kinerja pengelolaan keuangan berbasis IT, partisipasi anggaran dan peran kuasa pengguna anggaran. Metode pengumpulan data menggunakan angket. Penelitian melibatkan semua komponen dalam proses penganggaran, mendorong dan memberikan pelatihan menyangkut tata cara pengelolaan keuangan yang efektif, efisien dan transparan berbasis IT serta meningkatkan kulitas para pejabat pengelola keuangan.
\end{abstract}

Kata Kunci : kinerja, partisipasi, peran kuasa pengguna anggaran

ABSTRACT

The location of the study was the Dispora NTT Province which is located at Jalan Basuki Rahmat No. 1 Gedung E Lt. 3 Kupang City NTT. The purpose of the study is a general description of the performance of IT-based financial management, budgetary participation and the role of the power user of the budget. The data collection method uses a questionnaire. Research involves all components in the budgeting process, encourages and provides training regarding effective, efficient and transparent IT-based financial management procedures and improving the quality of financial management officials.

Keywords: performance, participation, the role of budget user authorities

\section{PENDAHULUAN}

Dinas Kepemudaan dan Olahraga (DISPORA) Provinsi NTT yang beralamat di Jalan Basuki Rahmat No. 1 Gedung E Lt. 3 Kota Kupang, menghadapi kendala kurangnya sumber daya manusia/brainware yang berkualitas, perangkat keras yang belum memenuhi standar teknis dan perangkat lunak belum terintegrasi. Hasil penelitian mengindikasikan belum maksimalnya Dispora Provinsi NTT dalam mengembangkan teknologi informasi pengelolaan keuangan. Kenyataannya terjadi pada Dispora NTT terlihat dari sedikitnya jumlah pegawai yang mengikuti proses penyusunan, perencanaan program kegiatan tanpa memberikan masukan dan pendapat sesuai pengetahuan dan latar belakang ilmu.
Perencanaan program yang akan diimplementasikan bersifat program lanjutan dari tahun-tahun sebelumnya. Partisipasi Kuasa Pengguna Anggaran masih kurang dalam seluruh komponen organisasi dalam perencanaan anggaran yang baik, penyusunan hingga pelaksanaan anggaran harus melihat transparansi dan akuntabilitas, disiplin anggaran, efisiensi dan efektifitas serta taat azas juga harusnya diperhatikan akan tetapi sebaliknya komitmen organisasi seringkali disepelehkan sebagai sesuatu yang tidak berpengaruh penting bagi kinerja keuangan, terlihat bahwa adanya pos-pos anggaran kegiatan maupun program yang menganggur bukan karena salah satu bentuk penghematan (efisiensi) anggaran, melainkan masih kurangnya sistem perencanaan anggaran dan berbelitnya 
prosedur pengadaan barang dan jasa serta lemahnya proses legislasi merupakan pengahambat proses layanan publik pada Dispora Provinsi NTT.

Berdasarkan latar belakang masalah tersebut, maka dapat diambil beberapa permasalahan dalam penelitian ini diantaranya : (1) Bagaimana gambaran tentang kinerja pengelolaan keuangan berbasis IT, partsipasi anggaran dan peran kuasa pengguna anggaran pada Dispora Provinsi NTT; (2) Apakah partisipasi anggaran dan peran kuasa pengguna anggaran secara simultan berpengaruh signifikan terhadap kinerja pengelolaan keuangan berbasis IT pada Dispora Provinsi NTT; (3) Apakah partisipasi anggaran dan peran kuasa pengguna anggaran secara parsial berpengaruh signifikan terhadap kinerja pengelolaan keuangan berbasis IT pada Dispora Provinsi NTT.

Menurut Fauzi (2008:5) Teknologi Informasi adalah teknologi yang memanfaatkan komputer sebagai perangkat utama untuk mengolah data menjadi informasi yang bermanfaat [1].

Terdapat 2 (dua) Penelitian terdahulu yakni ; Kunwaviyah Nurcahyani (2010) dengan judul Pengaruh Partisipasi Anggaran Terhadap KPA, dan Partisipasi Penyusunan Anggaran Keuangan Daerah terhadap Kinerja Manajerial (studi kasus pada DPPKAD Kabupaten Sukoharjo) dengan hasil yang menyatakan bahwa hasil analisis data $\mathrm{H}_{2}$ menunjukkan peran KPA terhadap kinerja manajerial berpengaruh positif sebesar 8,058 pada tingkat signifikansi sebesar 0,000 sehingga dapat disimpulkan bahwa peran manajer yang tinggi dapat meningkatkan kinerja manajerial satuan kerja perangkat daerah khususnya di DPPKAD Kabupaten Sukoharjo.

Arisha Hayu Pramesthiningtsyas (2011) tentang Pengaruh Partisipasi penyusunan Anggaran Terhadap Kinerja Manajerial, Melalui Komitmen Organisasi Dan Motivasi Sebagai Variabel
Intervening (Studi Kasus Pada 15 Perusahaan di Kota Semarang) dengan hasil penelitian yang menggambarkan bahwa tidak terdapat pengaruh langsung antara partisipasi anggaran terhadap kinerja manajerial. [3]

Secara umum dari beberapa penelitian diatas memiliki kelemahan dan kelebihan, yaitu Kunwaviyah Nurcahyani (2010) . Partisipasi anggaran tidak berpengaruh terhadap kinerja manajerial Kelebihan melalui persepsi inovasi [2]

\section{METODE PENELITIAN}

Dalam penelitian ini menggunakan metode angket. Data diperoleh melalui kuesioner. Pertanyaan yang disajikan dalam kuesioner berupa pertanyaan tertutup dan pertanyaan terbuka. Pertanyaan tertutup dibuat dengan menggunakan skala ordinal, untuk memperoleh data yang jika diolah menunjukkan pengaruh atau hubungan antara variabel. Sedangkan pertanyaan terbuka diperlukan untuk mendukung secara kualitatif dari data kuantitatif yang diperoleh dan akhirnya dapat digunakan untuk menarik kesimpulan. Populasi adalah pegawai bagian keuangan pada Dispora Provinsi NTT, dimana jumlah secara pasti yaitu 40 pegawai di bagian keuangan.

Data yang telah dikumpulkan, diolah dan dianalisis terlebih dahulu agar mempermudah dalam pengambilan keputusan. menggunakan analisis statistik; analisis kuantitatif.

Pemikiran Teoritis : Partisipasi Anggaran (X1) ; Keterlibatan, Interaksi, Proses penganggaran, Pertanggungjawaban anggaran. Peran Kuasa Pengguna Anggaran (X2) ; Peran Interpersonal, Peran Informasional, Peran Pengambil keputusan. Kinerja Pengelolaan Keuangan Berbasis IT (Y) ; Efektifitas, Efisiensi, Transparan.

\section{HIPOTESIS :}


H1 ; Diduga variabel partisipasi anggaran dan peran kuasa pengguna pada Dinas Kepemudaan Dan Olahraga Provinsi Nusa Tenggara Timur dikategorikan tinggi.

$\mathrm{H} 2$; Partisipasi anggaran dan peran kuasa pengguna angaran secara simultan memiliki pengaruh positif dan signifikan terhadap kinerja pengelolaan keuangan berbasis IT pada Dispora Provinsi NTT.

H3 ; Partisipasi anggaran dan Peran kuasa pengguna anggaran memiliki pengaruh positif dan signifikan terhadap kinerja pengelolaan keuangan berbasis IT pada Dispora Provinsi NTT.

\section{HASIL DAN PEMBAHASAN}

Responden yang ditetapkan dalam penelitian ini merupakan representatif dari keterwakian populasi PNS DISPORA Provinsi NTT yakni pegawai yang telibat langsung dengan pengelolaan keuangan. Karakteristik responden yang dipaparkan adalah berdasarkan golongan atau kepangkatan :

Tabel 1. Karakteristik Responden berdasarkan Golongan/Kepangkatan

\begin{tabular}{cccc}
\hline No. & $\begin{array}{c}\text { Pangkat/Golongan } \\
\text { Ruang }\end{array}$ & F & \% \\
\hline $\mathbf{1}$ & Pembina (IV) & 6 & 15 \\
$\mathbf{6}$ & Penata (III) & 22 & 55 \\
$\mathbf{1 0}$ & Pengatur (II) & 12 & 30 \\
$\mathbf{1 3}$ & Golongan (I) & - & - \\
\hline & Jumlah & $\mathbf{4 0}$ & $\mathbf{1 0 0}$ \\
\hline
\end{tabular}

Untuk dapat menggunakan instrumen penelitian dalam penelitian ini, maka perlu dilakukan pengujian atas instrumen-instrumen tersebut dengan menggunakan uji validitas dan uji reliabilitas.

Uji Validitas ; Variabel kinerja pengelolaan keuangan terdiri atas 3 (tiga) indikator dan 9 (sembilan) item pernyataan, variabel partisipasi anggaran terdiri atas 4 (empat) indikator dan 12 (duabelas) item pernyataan dan variabel peran kuasa pengguna anggaran terdiri atas 3 (tiga) indikator dan 9 (sembilan) item pernyataan. Hasil pengujian instrumen penelitian dengan melihat tingkat signifikan di bawah nilai 0,05 dengan menggunakan software SPSS versi 21 sehingga diperoleh hasil yang ditunjukan pada Tabel 2 berikut:

Tabel 2 Hasil Uji Validitas

\begin{tabular}{|c|c|c|c|c|}
\hline $\begin{array}{c}\text { Variab } \\
\text { el }\end{array}$ & $\begin{array}{c}\text { Ite } \\
\text { m }\end{array}$ & $\begin{array}{c}\text { Koefisi } \\
\text { en } \\
\text { Korela } \\
\text { si } \\
\end{array}$ & $\begin{array}{c}\text { r- } \\
\text { hitu } \\
\text { ng }\end{array}$ & Ket \\
\hline Kinerja & P1 & 0,409 & 0,3 & Valid \\
\hline \multirow{8}{*}{$\begin{array}{l}\text { Pengelo } \\
\text { laan } \\
\text { Keuang } \\
\text { an } \\
\text { Berbasi } \\
\text { s IT } \\
\text { (Y) }\end{array}$} & $\mathrm{P} 2$ & 0,591 & 0,3 & Valid \\
\hline & P3 & 0,399 & 0,3 & Valid \\
\hline & $\mathrm{P} 4$ & 0,494 & 0,3 & Valid \\
\hline & P5 & 0,320 & 0,3 & Valid \\
\hline & P6 & 0,381 & 0,3 & Valid \\
\hline & P7 & 0,371 & 0,3 & Valid \\
\hline & P8 & 0,357 & 0,3 & Valid \\
\hline & P9 & 0,510 & 0,3 & Valid \\
\hline \multirow{12}{*}{$\begin{array}{c}\text { Partisi } \\
\text { pasi } \\
\text { Anggar } \\
\text { an } \\
\text { (X1) }\end{array}$} & $\begin{array}{c}\mathrm{P} 1 \\
0\end{array}$ & 0,314 & 0,3 & Valid \\
\hline & $\begin{array}{c}\mathrm{P} 1 \\
1\end{array}$ & 0,345 & 0,3 & Valid \\
\hline & $\begin{array}{c}\mathrm{P} 1 \\
2\end{array}$ & 0,401 & 0,3 & Valid \\
\hline & $\begin{array}{c}\mathrm{P} 1 \\
3\end{array}$ & 0,525 & 0,3 & Valid \\
\hline & $\begin{array}{c}\mathrm{P} 1 \\
4\end{array}$ & 0,395 & 0,3 & Valid \\
\hline & $\begin{array}{c}\mathrm{P} 1 \\
5\end{array}$ & 0,312 & 0,3 & Valid \\
\hline & $\begin{array}{c}\mathrm{P} 1 \\
6\end{array}$ & 0,325 & 0,3 & Valid \\
\hline & $\begin{array}{c}\mathrm{P} 1 \\
7\end{array}$ & 0,398 & 0,3 & Valid \\
\hline & $\begin{array}{c}\mathrm{P} 1 \\
8\end{array}$ & 0,403 & 0,3 & Valid \\
\hline & $\begin{array}{c}\mathrm{P} 1 \\
9\end{array}$ & 0,440 & 0,3 & Valid \\
\hline & $\begin{array}{c}\mathrm{P} 2 \\
0\end{array}$ & 0,449 & 0,3 & Valid \\
\hline & $\mathrm{P} 2$ & 0,364 & 0,3 & Valid \\
\hline
\end{tabular}




\begin{tabular}{ccccc}
\hline $\begin{array}{c}\text { Peran } \\
\text { Kuasa }\end{array}$ & $\begin{array}{c}\text { P3 } \\
\text { Penggu }\end{array}$ & 0,499 & 0,3 & Valid \\
na & 5 & 0,467 & 0,3 & Valid \\
$\begin{array}{c}\text { Anggar } \\
\text { an }\end{array}$ & $\begin{array}{c}\text { P3 } \\
\text { (X2) }\end{array}$ & 0,362 & 0,3 & Valid \\
& P3 & 0,436 & 0,3 & Valid \\
& 7 & & & \\
& P3 & 0,367 & 0,3 & Valid \\
& 8 & & & \\
& P3 & 0,385 & 0,3 & Valid \\
& 9 & & & \\
& P4 & 0,357 & 0,3 & Valid \\
0 & & & \\
& P4 & 0,566 & 0,3 & Valid \\
1 & & & \\
& P4 & 0,327 & 0,3 & Valid \\
2 & & & \\
\hline
\end{tabular}

Uji Reliabilitas; menunjukan pada suatu pengertian bahwa suatu instrumen cukup dapat dipercaya untuk dapat menguji ketepatan diantara butir-butir pernyataan dalam instrumen penelitian.

Tabel 3 Hasil Uji Reliabilitas

\begin{tabular}{llccc}
\hline No & \multicolumn{1}{c}{$\begin{array}{c}\text { Variabe } \\
\mathbf{l}\end{array}$} & $\begin{array}{c}\text { Alph } \\
\mathbf{a ( \alpha )}\end{array}$ & $\begin{array}{c}\text { Jlh } \\
\text { Item }\end{array}$ & Ket \\
\hline $\mathbf{1}$ & $\begin{array}{l}\text { Kinerja } \\
\text { Pengelola } \\
\text { an } \\
\text { Keuanaga } \\
\text { n (Y) }\end{array}$ & 0,794 & 9 & Reliabel \\
$\mathbf{2}$ & $\begin{array}{l}\text { Partisipasi } \\
\text { Anggaran } \\
\text { (X1) }\end{array}$ & 0,670 & 12 & Reliabel \\
$\mathbf{3}$ & $\begin{array}{l}\text { Peran } \\
\text { Kuasa } \\
\text { Pengguna } \\
\text { Anggaran } \\
\text { (X2) }\end{array}$ & 0,715 & 9 & Reliabel \\
& & & \\
\hline
\end{tabular}

Analisis Statistik Deskriptif : Analisis data secara deskriptif bertujuan untuk menggambarkan bagaimana tanggapan responden untuk masing- masing indikator maupun secara total untuk variabel tersebut. Hasil jawaban tersebut selanjutnya digunakan untuk melihat tendensi jawaban responden mengenai kondisi masing-masing variabel dan indikator penelitian.

Kinerja Penggelolaan Keuangan Berbasis IT (Y) ; Kinerja Pengelolaan Keuangan berbasis IT merupakan keluaran/hasil dari kegiatan atau program yang telah dicapai sehubungan dengan penggunaan anggaran dengan kuantitaas dan kualitas yang terukur.

Berikut deskripsi jawaban responden terhadap variabel kinerja pengelolaan keuangan dengan item pernyataan 3 (tiga) indikator dari P1 - P9 dengan menggunakan rumus (Levis, 2013:175)

$$
P s_{-p}=\left(\frac{\bar{X} P s_{-p}}{5}\right) \times 100 \%
$$

Partisipasi Anggaran (X1) ; Partisipasi Anggaran merupakan terlibatnya pimpinan dan atau pegawai dalam proses penyusunan anggaran, penentuan tujuan anggaran dan dipertanggungjawabkan. Berikut deskripsi jawaban responden terhadap variabel partisipasi anggaran dengan item pernyataan empat indikator dari P10 - P21 dengan menggunakan rumus (Levis, 2013:175)

$$
P s_{-p}=\left(\frac{\bar{X} P s_{-p}}{5}\right) \times 100 \%
$$

\section{Peran Kuasa Pengguna Anggaran (X2) ;} Peran Kuasa Pengguna Anggaran merupakan aktivitas manajemen yang berkesinambungan dengan strategi yang efisien dan efektif dalam keuangan organisasi. Berikut deskripsi jawaban responden terhadap variabel kuasa pengguna anggaran dengan item pernyataan dua indikator dari P34 - P42 dengan menggunakan rumus (Levis, 2013:175) 


$$
P s_{-p}=\left(\frac{\bar{X} P s_{-p}}{5}\right) \times 100 \%
$$

Dari hasil capaian tersebut menunjukan bahwa variabel kuasa pengguna anggaran pada DISPORA Provinsi NTT menunjukan tingkatan yang tinggi, namun masi ada item yang belum mencapai rentang nilai yang tinggi, hal ini dikarenakan kuasa pengguna anggaran kurang menerima hasil partisipasi pegawainya dalam hal penentuan operasional dan anggaran yang tepat menyangkut pelaksanaan program kegiatan.

Analisis Statistik Inferensial : analisis statistik inferensial dilakukan dengan tujuan untuk membuktikan apakah data-data yang digunakan dalam penelitian ini telah memenuhi syarat normalitas atau tidak sehingga dapat digunakan dalam model regresi. Untuk mengetahui terjadinya normalitas data, maka perlu dilakukan uji asumsi klasik yang terdiri dari uji multikolinearitas, uji hetero kedastisitas, uji normalitas, dan uji linearitas Uji Asumsi Klasik :

\section{Uji Multikolinearitas ;}

Uji Multikolinearitas digunakan untuk mengetahui ada tidaknya hubungan yang kuat antara variabel independen yang digunakan. Model persamaan regresi yang baik seharusnya tidak terjadi korelasi yang tinggi diantara variabel bebas yaitu variabel partisipasi anggaran, komitmen organisasi dan peran kuasa pengguna anggaran. Untuk mendeteksi ada tidaknya multikol antara variabel bebas adalah dengan melihat nilai Tolerance dan lawannya Variance Inflation Factor (VIF). Jika nilai tolerance kurang dari 0,10 dan lawannya VIF lebih dari 10, maka ada indikasi adanya korelasi antar variabel bebas. Atau dengan kata lain jika nilai tolerance lebih dari 0,10 dan VIF kurang dari 10, dapat disimpulkan bahwa antar variabel bebas tidak terjadi multikolinearitas.

Uji multikolinearitas diolah menggunakan Program SPSS versi 21 for windows dan diperoleh hasil collearity statistics

Tabel 4 Uji Multikolinearitas

\begin{tabular}{|l|r|r|}
\hline \multicolumn{2}{|c|}{ Coefficients $^{\mathbf{a}}$} \\
\hline \multirow{2}{*}{ Model } & \multicolumn{3}{|c|}{$\begin{array}{c}\text { Collinearity } \\
\text { Statistics }\end{array}$} \\
\cline { 2 - 3 } & Tolerance & VIF \\
\hline (Constant) &, 882 & 1,134 \\
Partisipasi Anggaran &, 889 & 1,125 \\
Komitmen Organisasi &, 872 & 1,147 \\
Peran Kuasa Pengguna & & \\
Anggaran & &
\end{tabular}

Hasil analisis pada Tabel 3 diketahui nilai tolerance dari ketiga variabel bebas terbukti lebih besar dari 0,10 atau nilai tolerance diatas $10 \%$. Hasil perhitungan nilai VIF adalah kurang dari 10. Hal ini berarti tidak ada korelasi antara variabel bebas dan dapat disimpulkan bahwa tidak ditemukan masalah multikolinearitas antar variabel bebas dalam persamaan regresi linear berganda dalam penelitian ini.

\section{Uji Heteroskedastisitas ;}

Uji Heteroskedastisitas untuk memastikan bahwa data-data yang digunakan dalam sebuah model regresi tidak terjadi heteroskedastisitas atau yang diharapkan adalah data-data harus menyebar secara homogen (homoskedastisitas).

Uji heteroskedastisitas yang diolah dalam penelitian ini menggunakan program SPSS versi 21 for windows diperoleh scatterplot seperti Gambar 1. 


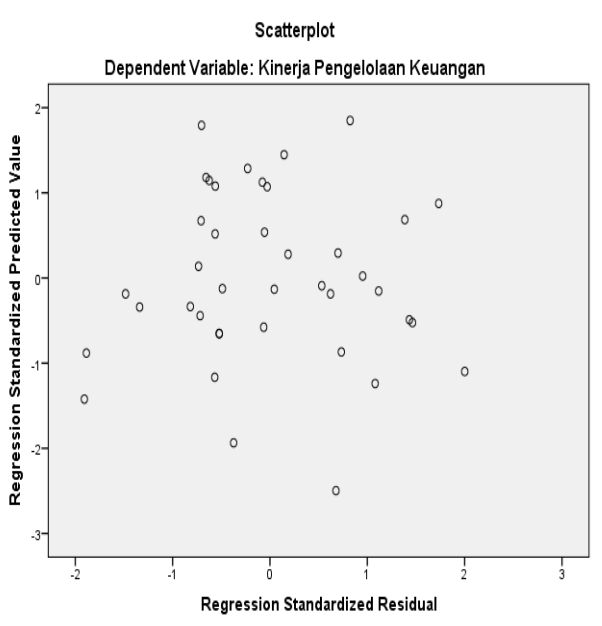

Gambar 1

Uji Heteroskedastisitas

\section{Uji Normalitas}

Salah satu syarat untuk menggunakan alat analisis regresi adalah data-data yang dianalisis harus menyebar secara normal atau mendekati normal. Alat yang digunakan untuk menguji normalitas data adalah dengan metode Analisa Grafik.

Hasil analisis pada grafik Histogram dan normal P-Plot menunjukkan bahwa data-data umumnya menyebar secara normal yakni terletak disekitar garis diagonal yang merupakan garis perpotongan antara garis probabilitas harapan dengan pengamatan. Uji normalitas diolah menggunakan program SPSS versi 21 for windows diperoleh normal p-plot of regression standar seperti pada gambar 2

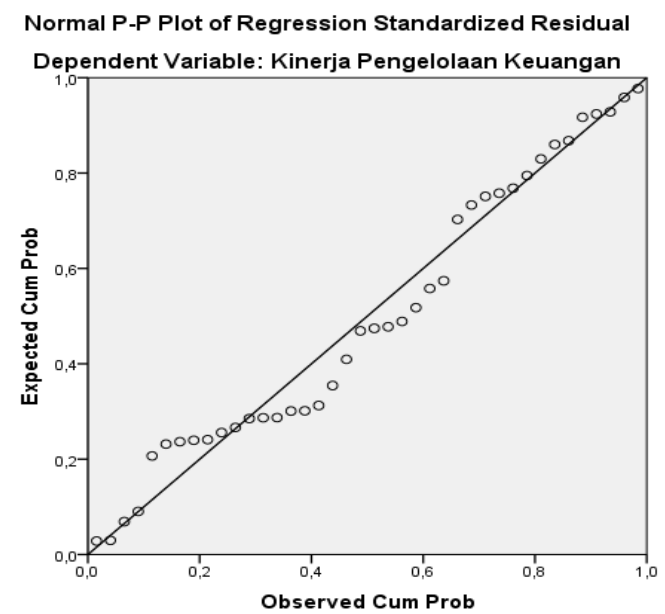

Gambar 2

Uji Normalitas

\section{Uji linearitas}

Digunakan untuk memastikan adanya hubungan liner antara varibel partisipasi anggaran (X1) dengan kinerja pengelolaan keuangan (Y), dan peran kuasa pengguna anggaran (X2) dengan kinerja kinerja pengelolaan keuangan (Y). Uji linearitas diolah menggunakan program SPSS versi 21 for windows seperti pada Tabel 4 berikut ini :

\section{Tabel 5}

Uji Linearitas

\begin{tabular}{|c|c|c|c|c|}
\hline \multirow[t]{2}{*}{ Varibel } & \multicolumn{2}{|c|}{ Linearity } & \multicolumn{2}{|c|}{$\begin{array}{c}\text { Deviation From } \\
\text { Linearity }\end{array}$} \\
\hline & $\mathbf{F}$ & Sig & $\mathbf{F}$ & Sig \\
\hline $\begin{array}{c}\text { Kinerja } \\
\text { Pengelolaan } \\
\text { Keuangan } \\
\text { *Partisipasi } \\
\text { Anggaran }\end{array}$ & $\begin{array}{c}9,89 \\
6\end{array}$ & ,004 & ,576 & ,805 \\
\hline $\begin{array}{l}\text { Kinerja } \\
\text { Pengelolaan } \\
\text { Keuangan } \\
\text { *Peran } \\
\text { Kuasa } \\
\text { Pengguna } \\
\text { Anggaran }\end{array}$ & $\begin{array}{c}11,5 \\
98\end{array}$ & ,002 & ,310 & ,965 \\
\hline
\end{tabular}

Berdasarkan Tabel 4 diketahui bahwa nilai signifikansi pada linearity pada setiap variabel kurang dari 0,05 dan pada deviation from linearity lebih besar dari 0,05, maka uji asumsi linearitas pada penelitian ini terpenuhi.

Analisis Regresi Linear berganda ; Model persamaan regresi yang baik adalah yang memenuhi persyaratan persyaratan asumsi klasik, antara lain semua data berdistribusi normal, model harus bebas dari gejala multikolinearitas dan bebas dari heteroskedastisitas. Dari analisis sebelumnya terlihat bahwa model yang diajukan dalam penelitian ini telah 
memenuhi syarat uji asumsi klasik sehingga model persamaan ini telah dianggap baik.

Analisis Regresi Berganda merupakan alat analisis untuk meramalkan nilai variabel terikat $(\mathrm{Y})$ apabila variabel bebas minimal dua atau lebih.

Hasil analisis regresi linear berganda dengan menggunakan program SPSS for windows versi 21 dapat dilihat tabel 5 berikut ini :

Tabel 6

Analisis Regresi Linear Berganda Coefficients $^{a}$

\begin{tabular}{|c|c|c|c|}
\hline \multirow[t]{2}{*}{ Model } & $\begin{array}{l}\text { Standardized } \\
\text { Coefficients }\end{array}$ & \multirow[t]{2}{*}{$\mathrm{T}$} & \multirow[t]{2}{*}{ Sig. } \\
\hline & Beta & & \\
\hline (Constant) & & 1,056 & ,298 \\
\hline $\begin{array}{l}\text { Partisipasi } \\
\text { Anggaran }\end{array}$ & 287, & 2,261 & ,030 \\
\hline $\begin{array}{l}\text { Peran } \\
\text { Kuasa } \\
\text { Pengguna } \\
\text { Anggaran }\end{array}$ & ,339 & 2,648 & ,012 \\
\hline
\end{tabular}

\section{KESIMPULAN}

Secara deskriptif, nilai persepsi responden variabel kinerja pengelolaan keuangan sebesar 73,67 \% masuk kategori setuju, nilai persepsi paling besar adalah variabel partisipasi anggaran dengan nilai persepsi responden $73,13 \%$ masuk kategori tinggi dan variabel peran kuasa pengguna anggaran mempunyai nilai persepsi responden yang paling kecil yaitu sebesar 72,11\% masuk kategori tinggi.

Secara inferensial variabel partisipasi anggaran berpengaruh positif dan signifikan terhadap kinerja pengelolaan keuangan pada Dispora NTT. Secara inferensial variabel komitmen organisasi berpengaruh positif dan signifikan terhadap kinerja pengelolaan keuangan pada Dispora NTT. Secara inferensial variabel peran kuasa pengguna anggaran berpengaruh positif dan signifikan terhadap kinerja pengelolaan keuangan pada Dispora NTT . Secara inferensial variabel partisipasi anggaran, komitmen organisasi dan peran kuasa pengguna anggran secara simultan berpengaruh positif dan signifikan terhadap kinerja pengelolaan keuangan pada Dispora NTT.

Besarnya kontribusi partisipasi anggaran, komitmen organisasi dan peran kuasa pengguna anggran terhadap kinerja pengelolaan keuangan pada Dispora NTT adalah $48,7 \%$, sedangkan sisanya adalah $51,3 \%$ dipengaruhi oleh faktor lain, misalnya pengetahuan dan kemampuan tentang pengelolaan keuangan, transparansi laporang keuangan dan lainnya yang tidak terdapat dalam penelitian ini.

\section{DAFTAR PUSTAKA}

[1] Fauzi, Akhmad. 2008. Pengantar Teknologi Informasi. Yogyakarta.Graha ilmu.

[2] Kunwaviyah, N. C. 2010. "Pengaruh Partisipasi Anggaran Terhadap Kinerja Manajerial Melalui Komitmen Organisasi dan Persepsi Inovasi sebagai Variabel Intervening". Semarang. UNDIP.

[3] Arisha, H. P. 2011. "Pengaruh Partisipasi Anggaran Terhadap Kinerja Manajerial Melalui Komitmen Organisasi dan Motivasi sebagai Variabel Intervening". Semarang. UNDIP.

[4] Levis, Leta Rafael. 2013. Metode Penelitian Perilaku Petani. Maumere: Ledalero. 